\title{
The influence of metal on the performance of 2,4,5-triphenylimidazole as an inhibitor of dengue virus replication
}

\author{
Sri Sumarsiha ${ }^{a}$, Muthia Dewi Pratiwi ${ }^{a}$, Indah Nur Ainnia, Hardinata Rachmad Sinatriya ${ }^{a}$, \\ Soegeng Soegijanto ${ }^{\mathrm{b}}$, Teguh Hari Sucipto ${ }^{\mathrm{b}}$, Harsasi Setyawati ${ }^{\mathrm{a}^{*}}$ \\ ${ }^{a}$ Department of Chemistry, Faculty of Science and Technology, Airlangga University, Surabaya 60119, Indonesia \\ ${ }^{b}$ Dengue Study Group, Institute of Tropical Disease, Airlangga University, Kampus C Jl. Mulyorejo, Surabaya, East Java, Indonesia, 60115
}

Received 12th April 2020 / Accepted 6th August 2020

\begin{abstract}
Dengue is a contagious disease caused by dengue virus and transmitted to humans by the bite of infected Aedes aegrpti mosquito. Imidazole and its derivatives are proven have ability impairing dengue virus. One of potential imodazole's derivatives is 2,4,5-triphenylimidazole (TPI). The presence of metal to the 2,4,5-triphenylimidazole (TPI) structure through a complex compound formation highly contributes to their ability as an inhibtor dengue virus replication. Iron, cobalt and zinc were used as an ion center in the complex compound. Complex Zn-TPI and Fe-TPI showed low cytotoxic effect at all the evaluated concentrations (viability $>50 \%$ ). Complex Co-TPI showed reduction of DENV-3 growth, at the lowest concentration $(6.25 \mu \mathrm{g} / \mathrm{ml})$ exhibited the antiviral activity (DENV-3 reduction 43\%). For Fe-TPI and $\mathrm{Zn}$ TPI, the reduction values of DENV-3 were $56 \%$ and $54.9 \%$ respectively.
\end{abstract}

Keywords: metal, 2,4,5-triphenylimidazole, influence, complex-compound, inhibitor, virus-replication

\section{INTRODUCTION}

Dengue is one of the most important public health problems affecting the global community. This disease commonly occurs in the tropic and sub-tropics area, and Indonesia becomes one of the countries that has the largest dengue-endemic region (E Setiati et al., 2006; Fahri et al., 2013; Kotaki et al., 2014). Until now, there is no vaccine or anti-viral for humans that could overcome this disease. Imidazole and their derivatives are proven has potency against dengue virus infection in cell lines (Sucipto et al., 2018; Sucipto et al., 2017). On the other hand, the presence of metal on the structure of organic ligand is proven could improve their biological activity (Geersing et al., 2018) The complex compound is formed as a result of metal and organic compound reaction. It can be used as an anti-inflammatory, antimicrobial, antifungal, antibacterial, and antivirus (Agotegaray et al., 2012; Arjmand, Mohani, \& Ahmad, 2005; Ranford, Sadler, \& Tocher, 1993). The metal complexes with deprotonated imidazole as ligand hold promise as an approach to enhance the biological activity. Previous reports have described the use of cobalt(II)-morin and zinc(II)-morin based systems for anti-DENV (dengue serotype) type 2 applications. The value of inhibition activity of zinc(II)-morin was $2.00 \mu \mathrm{g} / \mathrm{ml}$ and cobalt(II)morin was $3.08 \mu \mathrm{g} / \mathrm{ml}$ (Sucipto et al., 2017; Sucipto et al., 2019).

Thus, this research investigated the influence of metals on the imidazole derivative $(2,4,5$ triphenylimidazole) in their anti-dengue activity. Studies on the compound of imidazole-4,5showed higher antiviral potency against yellow fever virus (YFV) than dengue virus (DENV).

*Author for correspondence: Harsasi Setyawati, Department of Chemistry, Faculty of Science and Technology, Airlangga University, Surabaya 60119, Indonesia. Email - harsasi-s@fst.unair.ac.id 
This bioactivity may be within the imidazole series of a 'para- 'attachment of a heterocycle to its ' $C$ ' (Saudi et al., 2014).This research only focuses on Iron(II), Cobalt(II) and Zinc(II) as metal resources because three of them exhibit biological activity for humans and include as an essential mineral that needed by the humans body. The interaction of metals and 2,4,5-triphenylimidazole as a ligand was investigated through to the complex compound formation and characterized by spectrophotometer UV-Vis, spectrophotometer FTIR, and electron microscope. An inhibitor virus assay will be investigated through the ELISA (Enzyme-Linked Immunosorbent Assay) method using dengue virus type 3 .

\section{MATERIALS AND METHODS}

\section{Materials}

Materials used were pure analysis (pa) degree. They were 2,4,5-triphenylimidazole (TPI), zinc chloride $\left(\mathrm{ZnCl}_{2}\right)$, cobalt (II) chloride di hydrate $\left(\mathrm{CoCl}_{2} \cdot 2 \mathrm{H}_{2} \mathrm{O}\right)$, iron (III) chloride hexahydrate $\left(\mathrm{FeCl}_{3} .6 \mathrm{H}_{2} \mathrm{O}\right)$, N, N-dimethyl formamide (DMF), methanol, ethanol 95\%, distilled water, Vero cells derived from the kidney of an African green monkey from ATCC, Dimethyl Sulfoxide (DMSO) (Merck 99,98\%), Minimum Essential Medium Eagle (MEM) Media (Sigma-Aldrich), Fetal Bovine Serum (Biowest), L-glutamine, $\mathrm{NaHCO}_{3}$, Trypsin-EDTA, Dengue virus type 3 (DENV-3) Surabaya Isolate with GenBank accession number KF709426, Cell Proliferation Reagent WST-1 (Roche Applied Science), counting cells and DENV antibody (4G2) for Enzyme-Linked Immunosorbent Assay (ELISA).

\section{Synthesis and characterization of complex compounds from metal and 2,4,5- triphenylimidazole as a ligand}

All of the complex compounds were synthesized with the ratio mole metal to ligand $=1: 1$ (Martak et al., 2016; Sucipto \& Martak, 2016). The metal was dissolved by ethanol and reacted to the ligand (in ethanol) and then put in a $25 \mathrm{ml}$ flask and then refluxed for 4 hours at $76^{\circ} \mathrm{C}$. After that, the mixture was left until the sediment formed. Next, the sediment was separated from the filtrate then washed with $5 \mathrm{ml}$ of ethanol then dried in a desiccator (Martak et al., 2016). All of solids were characterized by Olympus light microscope, spectrophotometer UV-VIS and spectrophotometer FTIR.

\section{Vero cells preparation}

Vero cell lines (African green monkey kidney) was used in this study, maintained and propagated in Minimum Essential Eagle Medium containing $10 \%$ fetal bovine serum. Cultured Vero cell lines were incubated at $37^{\circ} \mathrm{C}$, respectively in $5 \% \mathrm{CO}_{2}$. Confluent monolayer of Vero cells were detached with trypsin-EDTA and incubate cells at $37^{\circ} \mathrm{C}$ for 5 minutes. Then Minimum Essential Eagle Medium containing 10\% fetal bovine serum was added by pipetting gently to break up any clumps of cells and counted using a Hemocytometer. Next, cells in 96-well plate with $1 \times 10^{6}$ cells $/ 10$ $\mathrm{ml}$ were added and incubated in $37^{\circ} \mathrm{C}$ incubator with $5 \mathrm{CO}_{2}$ cells were monitored daily until cells reached a $>90 \%$ confluent monolayer (Ammerman et al., 2008; Plotkin et al., 2018).

\section{Antiviral activities assay}

First, Vero cells were added with $2 \mathrm{ml}$ trypsinEDTA then incubated with $5 \% \mathrm{CO}_{2}$ at $37{ }^{\circ} \mathrm{C}$ for 5 minutes. Then, it was added with $8 \mathrm{ml}$ of the new MEM 10\% FBS and was vortexed until it was homogenous. After that, $10 \mu \mathrm{l}$ was pipetted and added with tryptophan blue strain. Then, the living cell was counted by a Hemocytometer counting chamber. This process required Vero cells $\left(1 \times 10^{6}\right.$ cells $\left./ 10 \mathrm{ml}\right)$ in a 96-well plate (Ammerman et al., 2008).

Second, preparation of a complex compound (each complex compound) was weighed 0.0006 gram, dissolved with $4 \mu \mathrm{L} \mathrm{DMF}$ and added by 996 $\mu l$ of MEM $10 \%$ FBS. Then, it was vortexed until homogeneous. After being homogeneous, $150 \mu \mathrm{l}$ of the complex compound was added in every well in U bottom plate and then added by $50 \mu \mathrm{l}$ MEM 10\% FBS to it. The first well line $50 \mu \mathrm{l}$ was pipetted which was then filled in the second well line and so on. This process gets complex compound with various concentrations (serial dilution).

To the flat bottom plate, was added by a mixture of $50 \mu \mathrm{l}$ of Vero cells, $25 \mu$ l of a complex compound, and $25 \mu \mathrm{l}$ of the DENV-3 $\left(2 \times 10^{4}\right.$ FFU/well). $100 \mu \mathrm{l}$ medium control and $100 \mu \mathrm{l}$ of 
cell control were added. Subsequently, the plates were incubated with $5 \% \mathrm{CO}_{2}$ at $37^{\circ} \mathrm{C}$ for 24 hours. Finally, the plate was verified using DENV antibody (4G2) for quantitative ELISA using Microplate Reader with a wavelength of $415 \mathrm{~nm}$ (Sucipto et al., 2018).

\section{Cytotoxicity assay}

First, Vero cells were added with $2 \mathrm{ml}$ trypsinEDTA then incubated with $5 \% \mathrm{CO}_{2}$ at $37^{\circ} \mathrm{C}$ for 5 minutes. Then, $8 \mathrm{ml}$ new MEM 10\% FBS was added and was vortexed until homogenous. After that, $10 \mu \mathrm{l}$ was pipetted and added by tryptophan blue strain. Then, the living cell was counted with a Hemocytometer counting chamber. This process required Vero cells $\left(1 \times 10^{6}\right.$ cells $\left./ 10 \mathrm{ml}\right)$ in a 96-well plate. Monitor cells until cells reach a $>90$ $\%$ confluent monolayer (Ammerman et al., 2008). Second, preparation of a complex compound (each complex compound) was weighed 0.0006 gram, dissolved with $4 \mu \mathrm{L} \mathrm{DMF}$ and added by 996 $\mu \mathrm{l}$ of MEM $10 \%$ FBS. Then, it was vortexed until it is homogeneous. Next, $150 \mu \mathrm{l}$ of the complex compound was added in every well in U bottom plate and then $50 \mu \mathrm{l}$ MEM 10\% FBS was added. The first well line $50 \mu \mathrm{l}$ was pipetted which was then filled in the second well line and so on. This process got the complex compound with various concentrations (serial dilution).

After that, a $50 \mu \mathrm{l}$ serial dilution was added to the Vero cells that had been prepared on the first day. Then, added 50 new MEM that containing $10 \%$ FBS. Then incubated 24 hours at $37^{\circ} \mathrm{C}$. After that second day, the supernatant was removed which was then washed twice with PBS. Then $100 \mu \mathrm{l}$ of the new MEM 10\% FBS was added and added $10 \mu \mathrm{l}$ of WST-1 reagent into Vero cells. Then the mixture was vortexed until homogeneous which is then incubated 30-60 minutes. After that, it is analyzed with a microplate reader with a wavelength of $450 \mathrm{~nm}$ and a reference wavelength of $650 \mathrm{~nm}$ (Sucipto et al., 2018).

\section{Statistical analysis}

Microsoft Excel 2010 for Windows was used to determine the cytotoxicity concentration 50 $\left(\mathrm{CC}_{50}\right)$, inhibitory concentration $\left(\mathrm{IC}_{50}\right)$ values of the complex compounds, $t$ test and standard deviation. A $p$ value of $<0.05$ was considered statistically significant.

\section{RESULTS AND DISCUSSION}

\section{Synthesis of complex compounds}

In this research, complex compounds were synthesized using the reflux method by reacting 2,4,5-triphenylimidazole (TPI) as a ligand and Fe, $\mathrm{Co}$ and $\mathrm{Zn}$ as a central atom. The complexes were synthesized using ratio mole metal to ligand 1:1. The obtained crystals were then put in the freeze dryer to make the complete dryness of crystal. The crystals that formed was characterized by light microscope (Figure 1). Complex Co-TPI and ZnTPI showed a perfect needle crystal. However, Fe-TPI showed a broken needle crystal. The broken crystal is caused by high heating temperature when crystallization step.

\section{Characterization of complex compounds}

Complex compounds that have been successfully synthesized then characterized to determine their nature and characteristic. The characterization was conducted by UV-Vis spectrophotometer and FTIR spectrophotometer.

Characterization using UV-Vis spectrophotometer was used to determine the maximum wavelength and UV-Vis spectra pattern in a compound. The crystalline of the complex compound was dissolved with DMF, then the absorbance was measured (Figure 2 and Table 1). Figure 2 and Table 1 show that there is a shift in the maximum wavelength of the complexes and the ligand. This peak shifted due to the density of asymmetric electric charges in the imidazole ring was altered after coordinated with metal ions. It will drive a shift over a wide absorption range because the metal ion has many electrons on the $\mathrm{d}$ orbital. Consequently, the $\pi-\pi *$ transition takes place easier. All complex compounds show the maximum wavelength in the UV region (under $400 \mathrm{~nm}$ ). This wavelength shows the metal-ligand charge transfer phenomenon which only has by complex compound (Deng et al., 2012). 


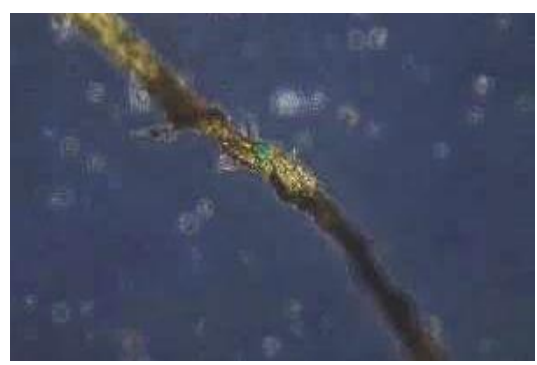

(a) Fe-TPI

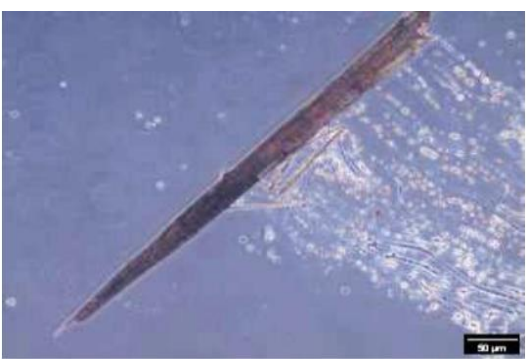

(b) Co-TPI

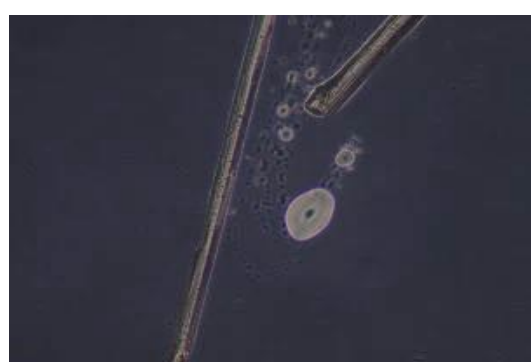

(c) Zn-TPI

Figure 1. Crystal of TPI- complex compounds. (a) for Fe-TPI complex (b) for Co-TPI (c) for Zn-TPI. Each solid has been characterized by light microscopes with 40x magnification.

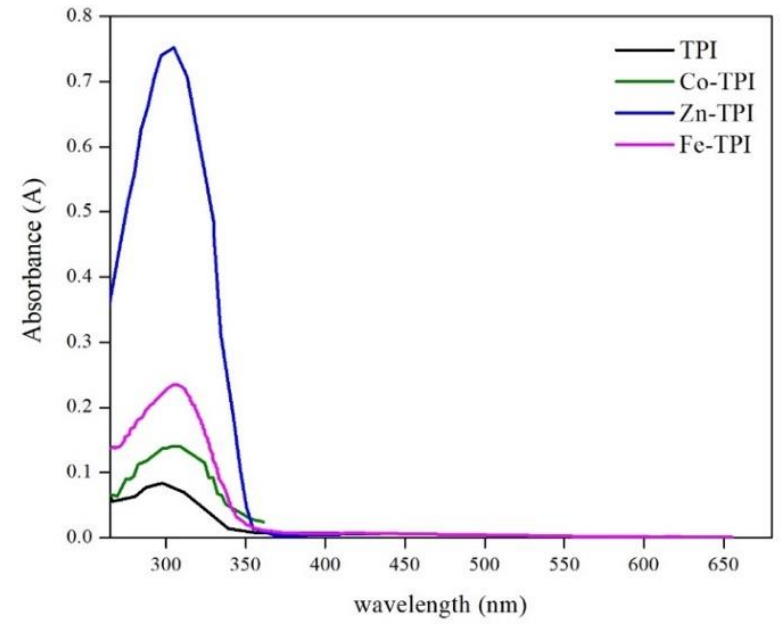

Figure 2. The electronic spectra of complex compounds on DMF solvent. All solutions were charcterized by spectrophotometer UV-VIS in the region $200-650 \mathrm{~nm}$.

Table 1. The maximum wavelength of complex compounds Fe-TPI, Co-TPI, Zn-TPI, and the ligand TPI. All compounds were soluted in DMF solvent.

\begin{tabular}{cc}
\hline Compound & Maximum wavelenth $(\mathrm{nm})$ \\
\hline TPI & 304 \\
Fe-TPI & 308.5 \\
Co-TPI & 309 \\
Zn-TPI & 306 \\
\hline
\end{tabular}

Characterization using FTIR spectrophotometer was used to determine the functional groups formed in the complex compound and to determine the bonds formed between metals and ligands. The result of the FTIR spectra shows that there are differences in the FTIR spectra of TPI ligands and the complex compounds (Figure 3 and Table 2).

If we compare the spectra of the ligand and the complexes, we can see that there is some shifted of the wavenumber on characteristic functional group. In other words, the metal is proven bonded to the ligand structure. From this characterization we also could conclude that all metals from complex compounds have bonded to the $-\mathrm{N}$ - functional group from ligand. (Figure $4)$.

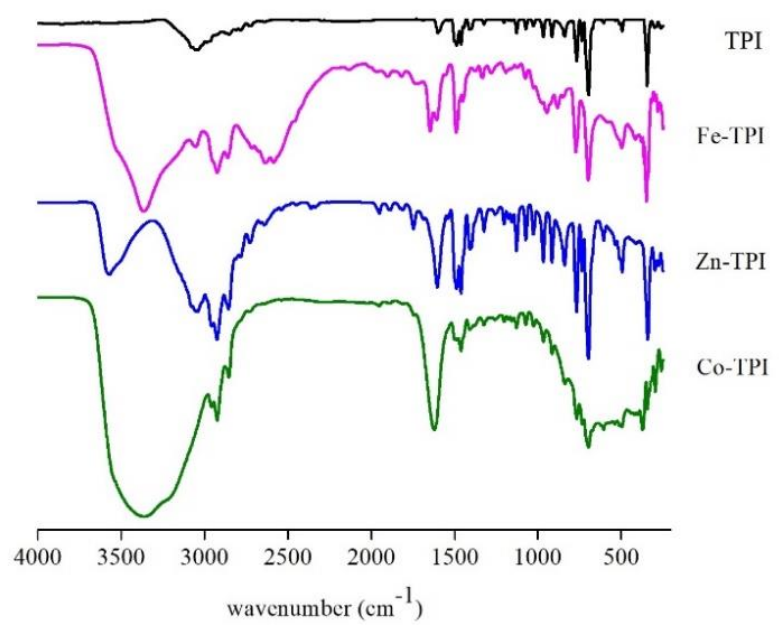

Figure 3. The FTIR spectra of complex compounds Fe-TPI, Co-TPI, Zn-TPI, and the ligand TPI. All compounds were characterized by FTIR the wavenumber range $3500-250 \mathrm{~cm}^{-1}$. 
Table 2. The FTIR spectra data of complex compounds Fe-TPI, Co-TPI, Zn-TPI. The spectra of complex compounds were compared with the ligand spectrum TPI.

\begin{tabular}{ccccc}
\hline Functional & \multicolumn{4}{c}{ Wavenumber $\left.\mathbf{( c m}^{-1}\right)$} \\
Group & TPI & Fe-TPI & Co-TPI & Zn-TPI \\
\hline Metal-N & - & 370.33 & 368.4 & 298.96 \\
O-H & 3591.45 & 3365.78 & 3379.28 & 3650 \\
N-H & 3100.34 & 3124.21 & 3367.71 & 3113.13 \\
C-H & 2924.47 & 2856.58 & 2924.09 & 2988.08 \\
C=C & 1601.65 & 1489.05 & 1504.48 & 1602.85 \\
C-N & 1129.09 & 1604.77 & 1627.92 & 1128.36 \\
\hline
\end{tabular}

Reference: (Badertscher et al., 2009).

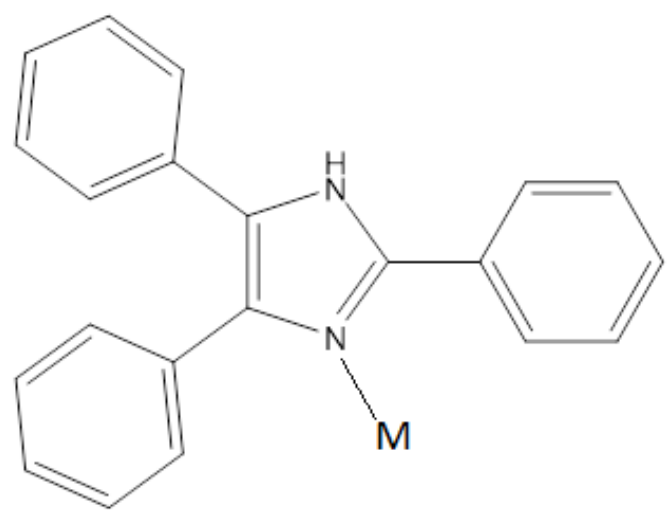

Figure 4. The bonding prediction of metal ion (M) with a functional group of TPI ligand. $\mathrm{M}$ is metal ion $\mathrm{Fe}, \mathrm{Co}$, and $\mathrm{Zn}$ that act as central ion of complex compound.

Anti-dengue activity of complex compounds. The purpose of this study is to find antiviral to DENV-2 using Vero cells line $\left(\mathrm{IC}_{50}\right)$. Vero cells could be infected by DENV as well as hepatocyte cells because the characteristic of the cell is similar to hepatocyte which is a host of dengue virus to replicate itself. The $\mathrm{CC}_{50}$ presented cytotoxicity level of complex compounds against the host, and the host used in the study was Vero cells.

Based on Table 3, all complexes have $\mathrm{IC}_{50}$ lower than their $\mathrm{CC}_{50}$ except Co-TPI. It means that almost all complexes are able to kill the pathogen before destroying the host cell. This condition is beneficial because the complex compound only kill the virus-cell without make suffering the host.

As shown in Figure 5, we can see that TPI and $\mathrm{Cu}$-TPI are classified as highly toxic compared by Fe-TPI and Zn-TPI which classified as a medium toxic. The inhibition at $\mathrm{IC}_{50}$ was not significantly higher $(p<0.005)$ compared to that of the metalfree imidazole $\left(\mathrm{IC}_{50}=0.38 \mu \mathrm{g} / \mathrm{ml}\right)$. But, the metalfree imidazole is more toxic for Vero cells $\left(\mathrm{CC}_{50}\right.$
$=2.91 \mu \mathrm{g} / \mathrm{ml})$. The level of toxicity of an extract is classified based on the $\mathrm{IC}_{50}$ value, which is a very high category (highly toxic) if it is able to kill $50 \%$ of larvae at a concentration of $1-10 \mu \mathrm{g} / \mathrm{ml}$, a medium category (medium toxic) at a concentration of $10-100 \mu \mathrm{g} / \mathrm{ml}$ and a low category (low toxic) at a concentration of $100-1000 \mu \mathrm{g} / \mathrm{ml}$ (Thiel et al., 1982) . For this purpose, we tested each compound at various concentration and observed that both Zn-TPI and Fe-TPI low exhibit any cytotoxic effect at all the evaluated concentrations (viability $>50 \%$ ). Compound CoTPI showed reduction of DENV-3 growth, at the lowest concentration $(6.25 \mu \mathrm{g} / \mathrm{ml})$ exhibited the antiviral activity (DENV-3 reduction 43\%). It showed reduction of DENV-3 56\% and 54.9\%.

In this study, medium control and cell control were treated without DENV-3. The data distribution of mean of response from each concentration was normal, with $p$-value more than 0.05. The response is a total energy from cell mitochondrial in each concentration of complexes. The value of response from medium control was $<0.001$ and value of cell control was $>2.63$, with analogy viability cells medium control is $0 \%$ and control cells is $100 \%$. The data in this study was analyzed by using t-test on Microsoft Excel 2010 and inhibition of compound to DENV-3 replication was significant ( $p$ value $<0.05$ ). The Figure 6 indicates the mean of response with its standard deviation.

The $\mathrm{C}$ terminal in the imidazole structure plays important role to improve cellular uptake and nuclear localization of complex compound. Besides, phenyl-imidazole has a great potential as drug candidate to treatment of a variety of viral diseases, phenyl rings in imidazole presence of electron withdrawing groups improved the biological activity (Sharma et al., 2009). 
Table 3. The anti-dengue activity of complex compounds in terms of cytotoxicity concentration.

\begin{tabular}{cccc}
\hline Compound & $\begin{array}{c}\text { Cytotoxicity } \\
\text { Concentration }\left(\mathbf{C C}_{50}\right) \\
(\boldsymbol{\mu g} / \mathbf{m l})\end{array}$ & $\begin{array}{c}\text { Inhibition } \\
\text { Concentration }\left(\mathbf{I C}_{50}\right) \\
(\boldsymbol{\mu g} / \mathbf{m l})\end{array}$ & Selectivity Index (SI) \\
\hline TPI & 36.75 & 1.46 & 25.17 \\
Fe-TPI & 1231.71 & 98.66 & 12.48 \\
Co-TPI & 509.14 & -56.29 & -9.04 \\
Cu-TPI & 44.17 & 2.30 & 19.20 \\
\hline
\end{tabular}

${ }^{*}$ Unpublished Data

(CC50), Inhibition Concentration (IC50), and Selectivity Index (SI). The anti-dengue activity of complex compounds was also compared with the ligand TPI.

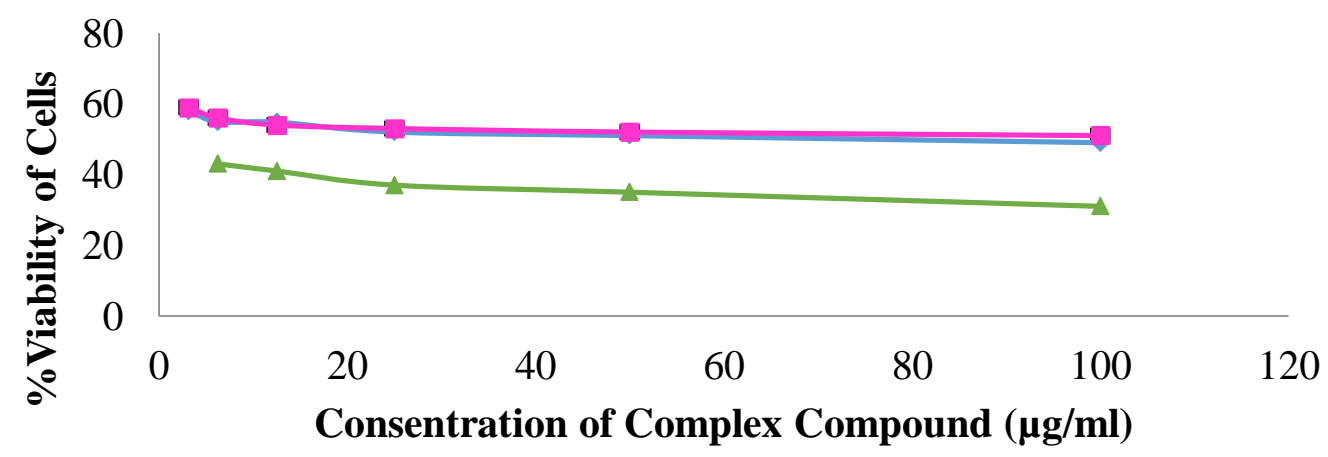

$\rightarrow$ Complex Zn-TPI $\rightarrow$ Complex Fe-TPI $\rightarrow$ Complex Co-TPI

Figure 5. The inhibition DENV-3 curve of complex compounds Fe-TPI, Co-TPI, and Zn-TPI. The inhibition activity was gained by analyzing the inhibition of Vero cells that treated with the complex compounds.

In the present study, the death cell rates were not determined for the Vero cells that were treated for $24 \mathrm{~h}$ by the complex compound with different concentrations. The results revealed that it was found that these complex compound stimulate almost same with Vero cells compared to control (data not shown), for example in the $200 \mu \mathrm{g} / \mathrm{ml}$ concentration of complex compounds not showed the cell death with shown viability of cells $>100 \%$ (Figure 7). This result demonstrates that three complex compounds did not cause the death cell or toxic effects on Vero cells. If the concentration of the compound is high, it will be toxic and could inhibit cell growth. A strong oxidative compound can cause cell death in more than one way: passive cell death, such as necrosis caused by the disruption of osmotic balance and apoptosis, such as active cell death caused by caspases. Based on previous research, active cell death is characterized by cytoplasmic vacuolation, largely in the endoplasmic reticulum and by the absence of caspases (cysteine proteases) (Sucipto \& Martak, 2016).

Compare with a previous study, for example Cu-TPI (Sucipto \& Martak, 2016), the result of cytotoxicity and antiviral activity of DENV-3 for three complex compounds in this study showed low cytotoxicity to Vero cells and high activity. Activity against human immunodeficiency virus type 1 (HIV-1) strain IIIB and HIV-2 strain ROD in MT-4 cells $\left(\mathrm{IC}_{50}\right)$ by $\mathrm{Zn}$ (II) with 3,14-dimethyl2,6,13,17-tetraazatricyclo(16.4.0.0 $\left.0^{7,12}\right)$ docosane) diacetate ligand were $3.50 \pm 0.33 \mu \mathrm{M}$ and $>110.67$ $\mu \mathrm{M}$ (Biot et al., 2012). 

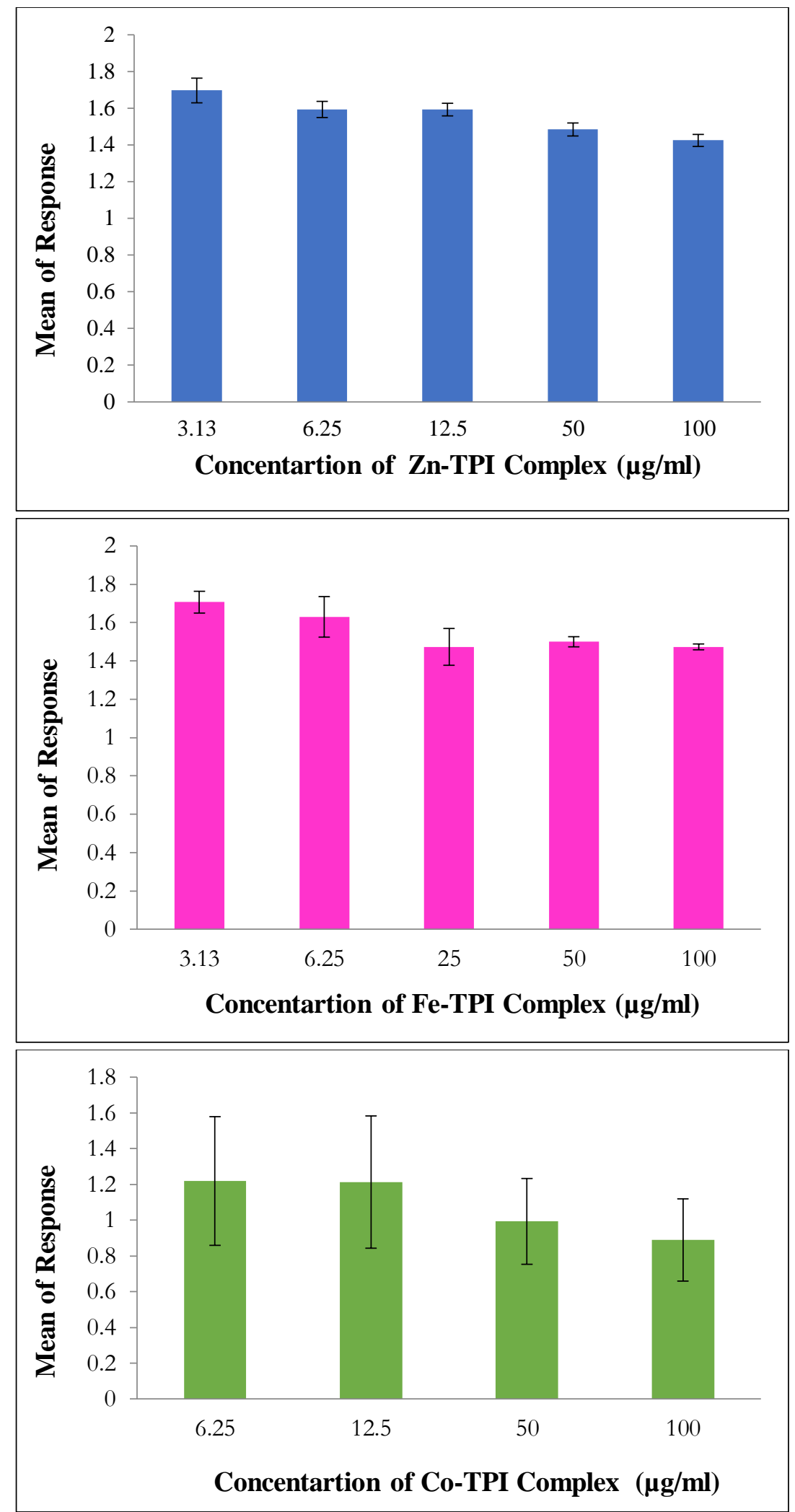

Figure 6. Standard deviation curve on the antiviral assay of complex compounds Fe-TPI, Co-TPI, and $\mathrm{Zn}$-TPI. For Fe-TPI and Zn TPI complex was analyzed in 5 concentrations. However, for the Co-TPI complex, in 4 concentrations. 


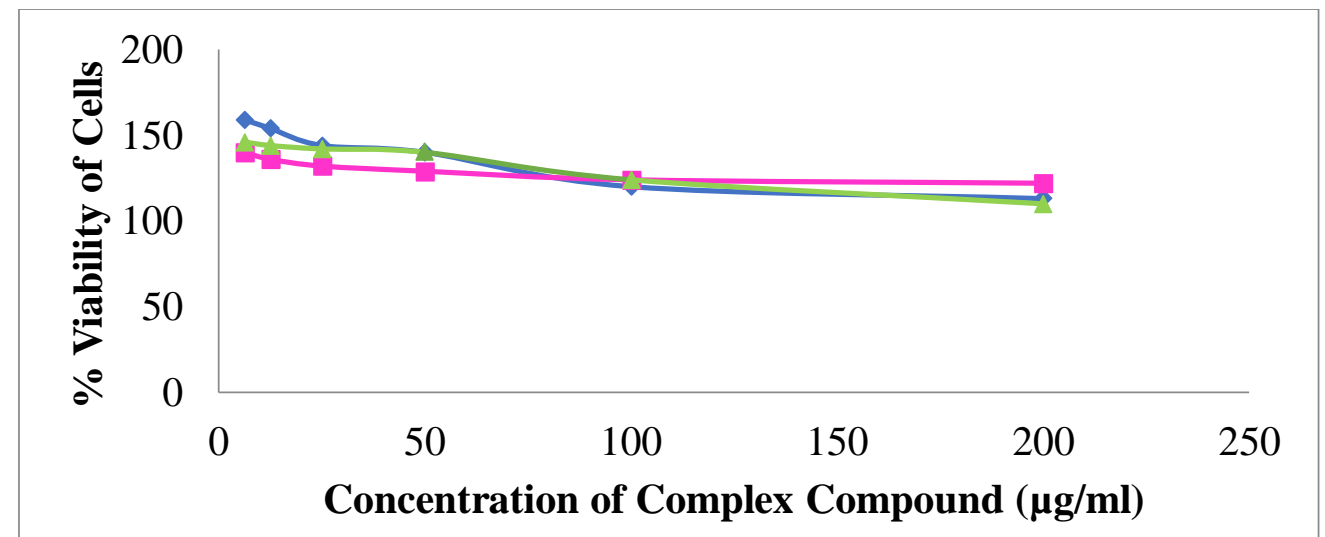

$\multimap$ Complex Zn-TPI $\rightarrow$ Complex Fe-TPI $\leadsto$ Complex Co-TPI

Figure 7. The cytotoxicity curve of complex compounds Fe-TPI, Co-TPI, and Zn-TPI. The cytotoxicity curve was gained by analyzing the cytotoxicity of Vero cells that treated with the complex compounds.

According to SI value, almost complex generate value more than 3 . This denotes that almost complex compounds has a high selectivity. A compound is said to have high selectivity if the SI value is $\geq 3$ and is said to be less selective if it has SI value $<3$ (Prayong et al., 2008). Selectivity means that only viral cells are attacked while normal cells are not attacked (Alali et al., 1999). For Co-TPI, the result shows negative on the $\mathrm{CC}_{50}, \mathrm{IC}_{50}$ and Selective Index (SI). This result revealed that this complex is highly toxic so the result will always be negative

\section{CONCLUSION}

This research successfully investigated the influence of metal presence on the anti-dengue activity of derivative imidazole. The interaction of metal and 2,4,5-triphenylimidazole was revealed through the complex compound formation. All of the obtained complex compounds showed a bathochromic shift of wavelength and indicate a metal-ligand bonding through $-\mathrm{N}$ - group from the ligand. Complex Fe-TPI and Zn-TPI showed potency as an inhibitor of dengue viruses. However, Co-TPI complex was not found to be potent as an anti-dengue candidate.

\section{REFERENCES}

Agotegaray, M. A., Dennehy, M., Boeris, M. A., Grela, M. A., Burrow, R. A., \& Quinzani, O. V. 2012. Therapeutic properties, SOD and catecholase mimetic activities of novel ternary copper (II) complexes of the anti-inflammatory drug Fenoprofen with imidazole and caffeine. Polyhedron 34(1): 74-83.

Alali, F. Q., Liu, X.-X., \& McLaughlin, J. L. 1999. Annonaceous acetogenins: recent progress. Journal of Natural Products 62(3): 504-540.

Ammerman, N. C., Beier-Sexton, M., \& Azad, A. F. 2008. Growth and maintenance of Vero cell lines. Current Protocols in Microbiology 11(1): A. 4E. 1-A. 4E. 7.

Arjmand, F., Mohani, B., \& Ahmad, S. 2005. Synthesis, antibacterial, antifungal activity and interaction of CT-DNA with a new benzimidazole derived $\mathrm{Cu}$ (II) complex. European Journal of Medicinal Chemistry 40(11): 1103-1110.

Badertscher, M., Bühlmann, P., \& Pretsch, E. 2009. Structure determination of organic compounds: Tables of Spectral Data: Springer.

Biot, C., Castro, W., Botté, C. Y., \& Navarro, M. 2012. The therapeutic potential of metal-based antimalarial agents: implications for the mechanism of action. Dalton Transactions 41(21): 6335-6349.

Deng, J., Guo, L., Xiu, Q., Zhang, L., Wen, G., \& Zhong, C. 2012. Two polymeric metal complexes based on polycarbazole containing complexes of 8-hydroxyquinoline with $\mathrm{Zn}$ (II) and $\mathrm{Ni}$ (II) in the backbone: Synthesis, characterization and photovoltaic applications. Materials Chemistry and Physics 133(1): 452-458.

E Setiati, T., FP Wagenaar, J., D de Kruif, M., TA Mairuhu, A., CM van Grop, E., \& Soemantri, A. 2006. Changing epidemiology of dengue haemorrhagic fever in Indonesia.

Fahri, S., Yohan, B., Trimarsanto, H., Sayono, S., Hadisaputro, S., Dharmana, E., Sasmono, R. T. 2013. Molecular surveillance of dengue in Semarang, Indonesia revealed the circulation of an old genotype of dengue virus serotype-1. PLoS Neglected Tropical Dissease 7(8): e2354.

Geersing, A., Se $\square$ gaud, N., van der Wijst, M. G., Rots, M. G., \& Roelfes, G. 2018. Importance of metal-ion exchange for the biological activity of coordination complexes of the 
biomimetic ligand N4Py. Inorganic Chemistry 57(13): 77487756.

Kotaki, T., Yamanaka, A., Mulyatno, K. C., Churrotin, S., Labiqah, A., Sucipto, T. H., Konishi, E. 2014. Continuous dengue type 1 virus genotype shifts followed by co-circulation, clade shifts and subsequent disappearance in Surabaya, Indonesia, 2008-2013. Infection, Genetics and Evolution 28: 4854.

Martak, F., Cahyani, N. W. D., Nugraheni, Z. V., \& Utomo, W. P. 2016. Properties and Toxicity of Cobalt (II) Complex with 2, 4, 5-triphenyl-1H-imidazole Ligand. Indonesian Journal of Chemistry 16(3): 260-267.

Plotkin, B. J., Sigar, I. M., Swartzendruber, J. A., \& Kaminski, A. 2018. Anaerobic growth and maintenance of mammalian cell lines. JoVE Journal of Visualized Experiments (137): e58049.

Prayong, P., Barusrux, S., \& Weerapreeyakul, N. 2008. Cytotoxic activity screening of some indigenous Thai plants. Fitoterapia 79(7-8): 598-601.

Ranford, J. D., Sadler, P. J., \& Tocher, D. A. 1993. Cytotoxicity and antiviral activity of transition-metal salicylato complexes and crystal structure of bis (diisopropylsalicylato)(1, 10-phenanthroline) copper (II). Dalton Transactions (22): 3393-3399.

Saudi, M., Zmurko, J., Kaptein, S., Rozenski, J., Neyts, J., \& Van Aerschot, A. (2014). Synthesis and evaluation of imidazole4, 5-and pyrazine-2, 3-dicarboxamides targeting dengue and yellow fever virus. European Journal of Medicinal Chemistry 87: 529-539.

Sharma, D., Narasimhan, B., Kumar, P., Judge, V., Narang, R., De Clercq, E., \& Balzarini, J. 2009. Synthesis, antimicrobial and antiviral evaluation of substituted imidazole derivatives. European Journal of Medicinal Chemistry 44(6): 2347-2353.

Sucipto, T. H., Churrotin, S., Setyawati, H., Martak, F., Mulyatno, K. C., Amarullah, I. H., Soegijanto, S. 2018. New copper (II)-imidazole derivative effectively inhibits replication of DENV-2 in vero cell. African Journal of Infectious Diseases 12(1S): 116-119.

Sucipto, T. H., Churrotin, S., Setyawati, H. S., Mulyatno, K. C., Amarullah, I. H., Ueda, S., Bendryman, S. S. 2017. Inhibitory activity of cobalt (II)-morin complex against the replication of dengue virus type 2. Indonesian Journal of Tropical and Infectious Disease 6(6): 141-144.

Sucipto, T. H., \& Martak, F. 2016. Synthesis of metal-organic (complexes) compounds copper (II)-imidazole for antiviral HIV candidate. Indonesian Journal of Tropical and Infectious Disease 6(1): 5-11.

Sucipto, T. H., Setyawati, H., Churrotin, S., Amarullah, I. H., Sumarsih, S., Wardhani, P., . . Soegijanto, S. 2019. Antidengue type 2 virus activities of zinc (ii) complex compounds with 2-(2, 4-dihydroxyphenyl)-3, 5, 7trihydroxycromen-4-one ligands in vero cells. Indonesian Journal of Tropical and Infectious Disease 7(5): 105-108.

Thiel, P. G., Meyer, C. J., \& Marasas, W. F. 1982. Natural occurrence of moniliformin together with deoxynivalenol and zearalenone in Transkeian corn. Journal of Agricultural and Food Chemistry 30(2): 308-312. 